\title{
Demokrácia az információs társadalomban
}

A tanulmány a demokrácia helyzetét elemezi az információs társadalom időszakában. Az elemzés során feltárulnak a demokratikus intézményrendszer korlátai, fény derül arra, hogy mennyiben támogatják a hálózatok a szabadságjogok gyakorlását jelenleg, és milyen eddig kiaknázatlan lehetőségeket rejt még magában. A tanulmány azt mutatja be, hogy a politika mennyiben befolyásolja az egyes demokratikus szabadságjogokat. Az írás azt is számba veszi, hogy az információs társadalom szakirodalmának jelentősebb alakjai milyen demokrácia fogalmakkal dolgoztak vízióik vagy elemzéseik megfogalmazásakor. Végül elemzésre kerül az is, hogy a politika miért van lépéshátrányban az információs társadalmak technokultúrális közegéhez képest.

Kulcsszavak: demokrácia, demokratikus intézményrendszer, hálózatok, szabadságjogok, információs társadalom

\section{Szerzői információ:}

\section{Faragó Péter}

Szociológus 1998-ban végzett a Miskolci Egyetem Bölcsészettudományi Karán. Ph.D. fokozatát a Budapesti Múszaki Egyetem Gazdaság- és Társadalomtudományi Karán szerezte 2006-ban. 2001 és 2004 között az MTA Szzociológiai Kutatóintézetében volt tudományos segédmunkatárs, majd 2004 és 2006 között az Országos Területfejlesztési Hivatalban (OTH) dolgozott köztisztviselőként, informatikai feladatkörben. 2006 szeptembere óta a Nemzeti Fejlesztési Ügynökség (NFÜ) munkatársa. 1997 óta a Polányi Mihály Szabadelvú Filozófiai Társaság, 1998 óta a Magyar Szociológiai Társaság tagja.

E-mail: Peter.Farago@MEH.HU

Így hivatkozzon erre a cikkre:

Faragó Péter. „, Demokrácia az információs társadalomban”.

Információs Társadalom VII, 4. szám (2007): 68-85. 
Faragó Péter

\section{Demokrácia az információs társadalomban}

\section{Bevezető}

A tanulmány célja, hogy a demokrácia helyzetét elemezze az információs társadalmak idôszakában. Az elemzés során feltárulnak a demokratikus intézményrendszer korlátai, fény derül arra, hogy mennyiben támogatják a hálózatok a szabadságjogok gyakorlását jelenleg, és milyen eddig kiaknázatlan lehetôségeket rejt még magában. Az írás azt mutatja be, hogy a politika mennyiben befolyásolja az egyes demokratikus szabadságjogokat. Továbbá számba veszi, hogy az információs társadalom szakirodalmának jelentôsebb alakjai milyen demokráciafogalmakkal dolgoztak vízióik vagy elemzéseik megfogalmazásakor. Végül magyarázatot próbál adni arra is, hogy a politika miért van lépéshátrányban az információs társadalmak technokulturális közegéhez képest.

\section{(Poszt)indusztriális demokrácia}

Amikor a demokrácia helyzetét az információs társadalom keretein belül szeretnénk meghatározni, a legkézenfekvóbbnek az túnik, ha elsóként a posztindusztrializmus - és ezáltal az információs-kommunikációs társadalom paradigma (IKTp) 1 - egyik „ốsatyjához", a kiváló amerikai szociológushoz, Daniel Bellhez fordulunk. Én ezúttal munkáinak nem azt a sokat emlegetett részét vesszem szemügyre, amely a gazdasági struktúraváltozásokat, a tudás szerepének felértékelódését követi nyomon, hanem a demokrácia és a szabadság kérdésével kapcsolatos megjegyzéseire fókuszálok. Bell, a méltatlanul keveset idézett „A kapitalizmus kulturális ellentmondásai” (The Cultural Contradictions of Gapitalism) címú munkájában a demokrácia következô definíciójával szolgál: „[a] demokrácia olyan társadalompolitikai rendszer, amelynek legitimitása a kormányzottak jóváhagyásán alapul, ahol a politikai aréna a legkülönfélébb szemben álló csoportok számára nyitott, és ahol az alapvetô szabadságjogok védelme biztosított" (Bell 1976, 14).

Eszerint a demokratikus társadalom kormányzókra és kormányzottakra oszlik, benne uralmi (vezetói-alárendelti) viszonyok alakulnak ki. A kormányzókat a kormányzottak szavazati joggal rendelkező csoportjának többségi szavazata alapján választják meg, mely a hatalmi, kormányzói pozíció legitimációjának alapja. A legitimitás itt annyit tesz, hogy a kormányzottak az államügyek intézésének jogát átruházzák a kormányzókra. A kormányzók ezáltal felettük hatalmi pozícióba kerülnek, a konkrét államügyekben a kormányzottak a következô választásig nem alkothatnak véleményt, puszta elszenvedôi lesznek a kormányzók döntésének. A politikai döntési jog átruházásának

'A továbbiakban az információs-kommunikációs társadalom paradigmára az IK'Tp, az információs-kommunikríciós technológia kifejezésre az IKT rövidítést használom. 
rendszerét nevezi a politikatudományi szakzsargon közvetett demokráciának. Ez a demokráciaforma vált uralkodóvá már az indusztrializmus korai időszakában is, és nincs ez másként a Bell által posztindusztriálisnak nevezett társadalmakban sem.

A posztindusztriális társadalom - Bell szerint - abban különbözik az ipari társadalomtól, hogy a profitnövekedést nem elsôsorban a termelés növelésétól, hanem az emberek által elvégzett munkától, tudásuktól, az ún. hozzáadott értéktốl várják (Bell 1976, 15). A posztindusztriális társadalomban már nem a materiális tulajdon az egyedüli hatalmi eszköz, hanem a tekintély, a szimbolikus tốkefajták mindegyike. „A posztindusztriális társadalom koncepció nem nyújt teljes képet a társadalmi rendról, sokkal inkább olyan kísérlet, amely a társadalmi struktúra [...] tengelyének változásait próbálja bemutatni és magyarázni. [...] A valódi különbség a mai modern társadalomban nem a termelés birtokosai és az egységes "proletariátus « között van, hanem a bürokratikus és tekintélykapcsolatokban azok között, akiknek hatalmában áll döntést hozni és akiknek nem (kiemelés - F. P.), bármilyen társadalmi szerveződésról legyen is szó - politikairól, gazdaságiról vagy társadalmiról" (Bell 1974, 119). A posztindusztriális társadalom koncepciója tehát a társadalmi (osztály)struktúra változásaira kíván rámutatni. Ez a változás a döntéshozatal lehetốségében ragadható meg leginkább, s így a döntéshozatal szabadsága vagy annak hiánya határozza meg az új hatalmi viszonyokat.

Anélkül, hogy itt részletesen vitatnám Bell posztindusztrializmus-elméletét, ${ }^{2}$ utalni szeretnék rá, hogy mennyire megtévesztő már maga a posztindusztriális fogalom is, amely igen erôteljesen azt sugallja, hogy végérvényesen meghaladtuk az évszázados ipari viszonyokat, a kapitalizmus klasszikus állapotát: a fogyasztói és osztályjellegú viszonyokat a társadalomban, a laissez-faire tókés viszonyokat a gazdaságban és a korábbi politikai anomáliákat. Igaz ugyan, hogy a megtermelt áru jellege, a termelés módja, valamint az értékesítés (marketing - sic!) módszerei sok esetben jelentôs változásokon mentek keresztül, de makroszintú gazdasági, társadalmi és politikai változásokról aligha számolhatunk be. Épp ellenkezóleg: minden eddiginél nagyobb volumenú ipari beruházásoknak lehetünk tanúi, melyek kielégíthetetlen energia- és nyersanyagigénnyel állnak elő, miközben minden korábbinál durvábban szennyezik a környezetet. Korunk politikai és gazdasági viszonyainak egyik legszebb példája az a jelenség, amikor az egyes nemzetközi ipari termelók már azzal reklámozzák magukat, hogy termékeik elôállítása során nem használnak gyermekmunkát!

Nem azt állítom, hogy ne mentek volna végbe a már közhelyességig ismételgetett változások a termelésben (a szolgáltató szektor megerősödése, a tudás szerepének felértékelődése, az állandó átképzés kényszere, a marketing túlértékelése), hanem amellett érvelek, hogy az ipari termelés, az indusztrialitás szerepe mit sem csökkent az utóbbi években; csúcsra járnak az ipari termelés legkülönbözóbb formái (élelmiszeripar, mikroelektronika, autógyártás stb.), amelyet a marketingeszközökkel felkorbácsolt extrém fogyasztási szokások tovább erôsítenek. Azért fontos, hogy mindezt világossá tegyük, mert a bennünket körülvevó kapitalizmus ugyan sok szempontból megíjult, a vizsgálatunk szempontjából fontos társadalmi és politikai változások azonban elmaradtak (balol-

${ }^{2}$ A posztindusztrializmus az egyik olyan elmélet, amely gátolja a valós gazdasági viszonyok és az azokból következó demokratikus deficitek feltárását, ezért az elmélet részletes kritikája régi adóssága a témával foglalkozó társadalomtudósoknak. 
dali kritikaként lásd pl. Szalai 2006). Állításom lényege éppen abban áll, hogy a valóban átalakult, (poszt)indusztriális, posztmodern, információs gazdasághoz képest a regnáló politikai struktúra még mindig a klasszikus ipari társadalom több száz éves politikai berendezkedésének alkotmányos elveire épül. A demokrácia lépéshátrányban van a gazdaság helyzetéhez, a technológia általa nyújtott lehetôségekhez és az ehhez kapcsolódó közgondolkodáshoz (az ún. gyakorlati élethez) képest. Az ebból adódó társadalmi (és személyes) feszültséget napról napra észleljük, bár magát a jelenséget és annak okait nehezen tudjuk megragadni. Az atlanti kultúra társadalmai egyszerre a szólásszabadság mintaállamai és az élet legkülönbözóbb területeinek rugalmasságát, kommunikálhatóságát, átláthatóságát hirdetik, ugyanakkor a demokratikus gyakorlatok mai merev formáit valami megváltoztathatatlan monumentumnak, „az elképzelhető demokráciák legjobbikának" tekintik. Nyitott hétköznapi élet, szabad gazdaság aligha létezhet hosszú távon a megfelelốen hozzáigazított demokratikus intézményrendszer nélkül. Politika, gazdaság és kultúra nem választhatók el egymástól egyazon életvilágon belül; az egyén élete minden szegmensében ugyanazokat az eszközöket szeretné alkalmazni, és nem érti, hogy az élet egyes területeinek rendkívüli rugalmassága, hogyan társulhat egy igen statikus, 19. századi formájában megkövesedett politikai élettel. Ez az inkoherencia leginkább gyakorlati (technikai) oldalról merül fel, s itt nem a homogén világkép igényéról, az elméleti koherencia kereséséról van szó. Az utóbbiakról folyó vita megmarad az értelmiség vékony rétegeinek.

A politikatudomány tankönyveiben alapvetôen két demokráciaformát szokás számbavenni. Az elsố a már említett közvetett vagy képviseleti demokrácia, amely az atlanti kultúra államaiban szinte kizárólagosan van jelen, még akkor is, ha a belóle kinövő államformák sok tekintetben eltérőek. Megkülönböztethetünk prezidenciális, félprezidenciális, illetve gyenge-prezidenciális (kormányfői) rendszereket, de vannak szép számmal alkotmányos monarchiák is. Több kisebb-nagyobb különbség lehet egy-egy ilyen rendszer között, parlamentáris, képviseleti jellegében azonban mindegyik megegyezik. Korunk demokráciája, a (poszt)indusztriális képviseleti demokrácia a kormányzók és a kormányzottak közé ékel egy választott képviseleti csoportot, amely az elsố hatalmi ágat alkotja, és amelynek mintegy féket kellene jelentenie az éppen kormányzók hatalmával szemben. A megválasztott képviselók azonban sokkal inkább kötődnek saját politikai csoportjukhoz és képviselôi érdekszférájukhoz, mint a választói akarat érvényesítéséhez, így elsősorban egy kormányzói vagy kormányellenzói program képviselối. Konkrét ügyekben alig-alig hallatnak önálló véleményt, konkrét választói képviseletet elvétve gyakorolnak. A néhány évente ismétlődố választásokon a kormányzott állampolgár csak egy-két nagyobb politikai erố programja között választhat, a választások közötti igen hosszú idôszakokban képtelen befolyásolni az államügyek intézését - hatalmát átadja, befolyását elveszti.

A képviseleti demokráciával szemben, Bell a közvetlen vagy „részvételi demokráciát” sem tartja valamiféle univerzális gyógyszernek, amely minden demokratikus deficitet megold. Ha az állampolgárokon múlna, szegregált iskolákat hoznának létre - utal Bell a Platón óta feszítô morális problémára-, de nem szabad figyelmen kívül hagynunk, hogy egyetlen régió sem független politikai entitás, hanem egy nagyobb politikai egység része, és így az egész társadalom etikai normáihoz kell alkalmazkodnia. „Röviden: a részvételi demokrácia egy újabb apropó arra, hogy a politikai filozófia klasszikus problémá- 
ját ismételten felvessük, vagyis hogy kinek és milyen szinten kellene kormányoznia, milyen döntéseket kellene hoznia, és mely társadalmi csoportra vonatkozólag" (Bell 1974, 366; 1976, 204). Nem elegendő az elitek ${ }^{3}$ etikai normáit, politikai és gazdasági érdekeit figyelembe venni, hanem a teljes társadalom normáihoz kell minden kérdésben igazodnunk. Ez pedig aligha valósítható meg egy olyan képviseleti rendszerben, ahol az egyén szinte semmilyen módon nem tud beleszólni a döntéshozatalba. Bell igen érzékeny erre a problémára, hiszen már „A posztindusztriális társadalom kialakulása” (The Coming of Post-Industrial Society) címú könyvében is felveti, majd a kaptalizmus ellentmondásairól írt könyvében szinte szóról szóra megismétli. Bell megállapításaiból következhet, hogy morális és politikai okokból egyaránt szükséges lehet egy, a totális részvételi és a totális képviseleti demokrácia közötti, a gyakorlatban is múködóképes átmeneti demokratikus intézményforma kialakítása.

\section{Demokratizáló technológiák?}

A technika által elbúvölt kutatók, így az IKTp képviselőii is igen gyakran a technikai determinizmus csapdájába esnek, és ezért gyakorta a par excellence technológia demokratizáló hatása mellett érvelnek. ${ }^{4}$ Elsóként vegyük szemügyre Armand Mattelartnak „Az információs társadalom története” címú összefoglaló munkáját, emeljünk ki néhány általa idézett klasszikus szerzốt, és figyeljük meg, ók miként vélekednek a technika demokratizáló hatásáról.

Mattelart elsóként Alexandre-Théophile Vandermonde, a neves 18. századi francia hegedúmúvész, kémikus és matematikus kijelentését idézi, aki a következóképpen érvelt egy technikai találmány mellett: „Elhangzott egy gondolat a távíróval kapcsolatban, ami számomra végtelenül igaznak túnik, amely érezteti ennek teljes jelentôségét: nevezetesen, hogy e találmány lényege lehetôvé teszi a demokrácia meggyökerezését egy nagy népnél” (Mattelart 2004, 31).

Igen optimista Lewis Mumford is, aki egyébként igen kritikusan viszonyult a technikai fejlódés és az ember kapcsolatához: „Mindenhol, ahol az új technológia eszközei elérhetốek, és ahol közös nyelvet beszélnek, napjainkban olyan politikai egység elemeit fedezhetjük fel, amely szinte a régi Attika legkisebb városaihoz hasonlítható" (Mattelart 2004, 48).

A kibernetika atyjaként is számon tartott matematikus-filozófus Norbert Wiener szerint decentralizált jellege révén az információ lesz a „második ipari forradalom” forrása: e forradalom hordozza majd az emberek felszabadításának ígéretét (Mattelart 2004, 48). Ebból következóen az IKT-eszközeit is a szabadság növelésének eszközei közé kell sorolnunk.

\footnotetext{
${ }^{3}$ Amikor elitekról beszélünk, akkor meg kell különböztetnünk politikai, gazdasági, kulturális és médiaeliteket. Ezek mindegyike viszonylag jól elkülönüló csoportként van jelen a társadalomban, s így saját érdekei, jellemzói vannak. Átfedések, csoportközi kapcsolatok természetesen léteznek az elitek között is, összességükben mégsem tekinhetók egységes társadalmi csoportnak.

${ }^{+}$Dányi Endre és Sükösd Miklós kiválló tanulmányukban óket nevezi technoutópistáknak, szemben a technika elidegenítố, eldologiasító jellegét hangsúlyozó szerzókkel, akiket technopesszimistáknak titulálnak (Dányi-Sükösd 2003, 289-290).
} 
Bell a „részvételi társadalommal” (demokráciával) szemben érzett fenntartásainak adott hangot több múvében is - támasztja alá a fent is megfogalmazottakat Mattelart -, a kortárs Amitai Etzioni szerint viszont a posztmodern társadalom feladata, hogy megnyissa a „tömeges részvétel” korát. A Minerva névre keresztelt részvételi technológiai rendszert Etzioni azért tervezte meg, hogy „elősegítse a kábeltelevízió felhasználását a helyi igazgatási szintû döntésfolyamatok demokratizálódásának keretei között” (Mattelart 2004, 105).

Mattelart szerint Yoneji Masuda olyan társadalmat ígér, ahol a társadalmi részvétel politikai és erkölcsi értékké válik, ahol „a központosított hatalom és a hierarchia egy "sokközpontú társadalomnak" adja át a helyét" (Mattelart 2004, 112).

A fenti szerzók mindegyike valamilyen módon a technológiai fejlődés és a demokrácia erősödése közötti összefüggés elkötelezett híve. A téma egyik legmarkánsabb determinista IK'Tp írását mégsem a fenti klasszikus szerzók valamelyike, hanem Christopher Kedzie, a RAND Corporation egyik disszertánsa fogalmazta meg. Kedzie munkájában párhuzamos forradalmakról beszél, amelyek egyidejúleg határozták meg az 1980-as évek végének politikai és kulturális miliôjét: egy idôpontra vezethetô vissza a kelet-európai szocialista országokban a demokratikus fordulat és az IK'T elterjedésének kezdete. Kedzie azt a hipotézist kívánja igazolni, hogy „,a demokrácia és a hálózati kommunikáció között pozitív korreláció van” (Kedzie 1997). Szerinte a technológiai fejlődés erôteljesen támogatja a demokráciát, s az esettanulmányként bemutatott szovjet példa azt igazolja, hogy az IK'T szovjetunióbeli elterjedésének komoly szerepe volt az egypártrendszer demokratizálásában.

Igaz, hogy a kommunikációs csatornák felszabadulása, kibővülése kaput nyit a szólásszabadság elött, mégis nehezen igazolható, hogy miért vezetne ez közvetlenül és kizárólag egy egypártrendszerú ország demokratizálódásához. Ez a technikai determinizmus egyik klasszikus példája, amely nézet általában az új technológiák megjelenésével párhuzamosan tör elő annak lelkes hívei körében. Kedzie determinizmusa nemcsak a determinizmussal szemben felhozható klasszikus érvek miatt téves, hanem azért is, mert nem világos, hogyan alakul ki oksági viszony a kommunikációs technológiák és a demokratizálódó intézményrendszer között.

Ha megfordítjuk a helyzetet, talán még világosabban látszik a probléma. Igaz, hogy az egypártrendszerben a politikai diktatúra nyer a kommunikációs csatornák korlátozásával és az azok fölötti kontroll fenntartásával, de a teljes kontroll puszta megszüntetése még nem vezet közvetlenül demokratikus politikai intézményrendszerhez. Erre a mai Kína nyújtja a legnyilvánvalóbb példát. Itt az utóbbi évtizedben nemcsak az IKT-eszközök terjedése kaptott szárnyra, de a kapitalista gazdaság egy speciális formájának is teret engedett a kínai rezsim, miközben változatlan erôvel és hatékonysággal hárít el minden demokratizáló kísérletet politikai téren. Sót Kína azzal a feltétellel nyitotta meg piacait a kapitalista gazdaság s így az egész IKT-szektor elő́tt, hogy az atlanti külpolitika nem támadja tovább a kínai egypártrendszert. ${ }^{5}$ Egyelốre úgy tủnik, hogy

\footnotetext{
${ }^{5} \mathrm{Ez}$ az a folyamat, amelyet a Nyugat sikeresen túl is teljesített az olimpia odaítélésével, amellyel végérvényesen legitimált egy diktatorikus politikai berendezkedésú, mégis tốkés gazdasági viszonyok között élố országot. Ezzel a nyugati politika (élén természetesen az USA-val) egyszersmind kifejezésre juttatta, hogy milyen mértékben védelmezóje a polgári demokráciának, s mennyire elkötelezett híve a kapitalista gazdaságnak.
} 
Kína sikerrel korlátozza az IKT-szektort olyan szinten, amely már éppen elegendố a rendszer fenntartásához, de még nem lehetetleníti el a piacgazdaság fenntartásához szükséges kommunikációt. Ez persze megint csak alátámasztja s nem aláássa az IKT társadalmi szerepének jelentôségét, hiszen többek között az IKT-biztosította viszonylagos nyitottság ad lehetôséget arra, hogy egy demokratikus és fejlődố társadalom látszatát keltve Kína legitimálja hatalmi pozícióit a nyugati társadalmak elótt. Az atlanti politika gazdasági érdekek által erósen motivált engedékenységének köszönhetően válhatott Kína szalonképes félkapitalista e-diktatúrává.

\section{Demokrácia a hálózatok világában}

Az IKTp kutatói a demokrácia problémáit mindeddig alapvetốen a hálózati szabadság dimenziójában tárgyalták. Elsóként azt a kérdést vetették fel, hogy mennyiben teljesülnek az esélyegyenlőség alapelvei az internethez való hozzáférés területén. Másik alapvetô kérdésként pedig az merült fel, hogy az internet adta publikálási és kommunikációs lehetôségek milyen mértékben korlátozhatók. Az egyik szélsố álláspont szerint ugyanazokat a jogi szabályozókat kellene az internetre is alkalmaznunk, mint a hétköznapi életben, vagyis az off-line médiában, így minden internetes tartalmat megfigyelés és szigorú szabályozás alá kellene vonnunk. Ennek elvi és gyakorlati ellenzói képviselik a másik szélsớ álláspontot, mely szerint az internetes publikálási lehetôségek és kommunikációs csatornák szabadságfokát a maximumon kellene tartanunk, ezzel mintegy enyhítve azt a demokratikus deficitet, amelyet maguk a demokratikusnak nevezett politikai rendszerek termelnek ki. A két szélsó álláspont közül ma még mindig inkább az utóbbihoz állunk közelebb, még akkor is, ha az államok és a nemzetközi informatikai lobbik igyekeznek megfigyelésük, befolyásuk alá vonni az új médiumokat is, s a hálózatokon kívül már régóta alkalmazott korlátozási eszközöket szép lassan igyekeznek becsempészni a hálózati kommunikáció szabályozásába.

Ha egy pillanatra megpróbáljuk a paradigma kínálta viszonylag új szemüveget egy korábbira cserélni, az információs társadalomnak nevezett (poszt)modern társadalomforma és a demokráciafogalom közötti alapvető kapcsolat már kevésbé fogja elkerülni figyelmünket. Az IK'Tp kutatói eddig fóként a belsơ, a hálózati szabadság és demokrácia kérdésével foglalkoztak, és minden olyan szempontot, amely a külsó, a hálózaton kívüli szabadság és demokrácia kérdésére vonakozik, csak viszonyítási pontként, segédeszközként vagy szabályozó mintaként használtak a hálózat védelme, szabályozása vagy éppen korlátozása érdekében. ${ }^{6}$ Ha hajlandók vagyunk egy rövid időre magunkon hagyni régi szemüvegünket, nemcsak az történik, hogy a korábbi kérdések egészen új módon fogalmazódnak meg számunkra, hanem egészen új problémafelvetésekkel, kérdésekkel leszünk gazdagabbak.

Az egyik legalapvetóbb kérdés, hogy mennyiben járulnak hozzá a hálózatok a politikai élet demokratizálódásához, ill. hozzájárulnak-e egyáltalán. Ahhoz, hogy feltérképezhessük, hogy milyen hálózati eszközökkel, módszerekkel járulhat hozzá az IKT-

${ }^{6}$ A belsô-külsô szabadság fogalmi elválasztása természetesen erôsen analitikus, a gyakorlatban nincs merev határ a két terület között. 
szektor a demokratikus deficitek csökkentéséhez, világossá kell tennünk mi a különbség a belső és a külső szabadság között. Milyen e két szabadságforma viszonya egymáshoz? Mennyiben előfeltétele egyik a másiknak? Létezhetnek-e egymástól függetlenül szabályozott $s z a b a d s a ́ g t e r e k$ a társadalmi valóságban? Fel kell tehát térképeznünk, milyen hálózataink vannak, és milyen azok egymáshoz való viszonya.

\section{Úton a mobilhálózatok felé}

Nemrég jelent meg egy, az interneten belüli szólásszabadság (belsố szabadságtér) kérdéséról szóló igen alapos munka, melynek szerzóje Bayer Judit (Bayer 2005). A könyv részletesen elemzi a hálózati szabadság körüli igen összetett hazai és nemzetközi jogi környezetet, kiemelve a hangsúlyos uniós jogszabályokat, minden esetben összevetve ezeket az amerikai precedensekkel.

Bayer helyesen állítja szembe egymással az internetes szabadságtörekvések két ellentétes tendenciáját (Bayer 2005, 21). Az elsó a szabadságjogok maximalizálása, amely a jogi lehetôségek tágítását, az internet szempontjából releváns szabadságformák (elsốsorban a szólásszabadság) minél csekélyebb korlátozását jelenti. A másik a szabadságjogok ellenôr «ésére való törekvés, amely a felhasználók szabadságának korlátozását, az általuk használt hardverek, szoftverek és hálózatok kontrollját jelenti.

A maximalizálás, a szabadságtér tágítása nyilvánvalóan az érdekeit érvényesíteni kívánó állampolgár érdeke, míg az ellenốrzés, korlátozás, a szabadságtér szúkítése alapvetốen a fó kontroller államé, valamint a piacilag érdekelt informatikai nagyvállalatoké. Állam és állampolgár ellentétes politikai viszonya klasszikus politikatudományi probléma, melyet az elóbbiekben már részleteztem, most pedig kitérek a piaci nagyvállalatok kontrollszerepére is. „A nagyvállalatok célja, hogy ne maradjanak ki a felhasználó és az információ közötti, egyre rövidebb láncból. El kell érniük, hogy a felhasználónak szüksége legyen a termékükre. [...] A szabályozási kérdés tabuként kezelése nem más, mint a kezdeményezés átengedése a gazdasági érdekcsoportok számára. A kormányzatnak következetesen ki kellene állnia a szabadságjogok minél tejesebb érvényesülése, az új technológia demokratikus jellegú (sic!) használhatósága mellett. Az állami beavatkozás teljes elutasítása nem más, mint a véleménynyilvánítási szabadság liberális értelmezésének eltorzítása" (Bayer 2005, 21-22).

Bayer Judit álláspontja világos: az internet által kínált szabadságtér hosszú távon csak az állami beavatkozás segítségével tartható fenn. Ellentmondásos módon a tisztán piaci viszonyok egyáltalán nem garantálják a szabad információáramlást, állami kontroll nélkül éppen hogy veszélyeztetik azt. Az IKT-cégek monopolizáló törekvéseit Bayer a szoftverhasználat felól közelíti meg, s ebben a cégek három törekvésére mutat rá: 1. elhitetik a fogyasztókkal, hogy az ố termékük a legjobb; 2. elérik, hogy a kormányzati szabályozás kötelezóvé tegye szoftverük használatát; 3. bizonyos kommunikációs funkciókat elérhetetlenné tesznek a termék használata nélkül.

Ha a piaci szereplók körét nem korlátozzuk a szoftvergyártókra, akkor még számos más, a szabadságtér mesterséges korlátozását célzó törekvést is meghatározhatunk: elég ha a copyright kérdésével szorosan összefüggó le- és feltöltési szabadságot vagy a hardverkapacitások mesterséges fokozásának tendenciáját említjük. Anélkül, hogy részlete- 
sen számba vennénk minden érintett informatikai szegmenst, levonhatjuk azt az általános következtetést, hogy az állam szerepe alapvetố a szabadságtér garantálása szempontjából. Ugyanakkor nem hagyhatjuk figyelmen kívül azt sem, hogy a piaci szereplók érdekeltek abban, hogy újabb és újabb szabadságtereket nyissanak számunkra. Ilyen termékek például a mobiltelefonok, a wi-fi hálózati eszközök vagy az egyre népszerúbb hibrid mobil készülékek. Ezek - az előzô példákkal ellentétben - kifejezetten növelik a kommunikáció szabadságfokát még akkor is, ha hardver- és szoftverpiacaikon hasonló korlátozó tendenciák kialakulása valószínúsíthetố, mint a személyi számítógépek esetén.

A mobil eszközök és a demokratikus intézményrendszer kapcsolatáról érdekes írásokat olvashatunk a Mobil Democracy címú, Nyíri Kristóf által szerkesztett konferenciakiadványban (Nyíri 2003). Az írások kivétel nélkül a mobiltelefónia legjellemzóbb demokráciaerôsítố tulajdonságának a megerốsödött kommunikációs szabadságot tartják. A Fortunati által mobildemokráciának (cell-democracy) nevezett jelenséget a társadalomtudósok általában „vitatkozó”, „beszélgetô” vagy „csevegô” társadalomként írják le (Fortunati 2003, 241). Ezzel ugyan valóban erôsödik a kommunikációs elérés és elérhetóség szabadsága, viszont nem erôsödik tôle a sokkal fontosabb politikai szabadság. A mobildemokrácia ilyen formában bevezetett fogalma kissé félrevezetô, hiszen a mobilizált kommunikáció lehetôsége még nem vezet közvetlenül a politikai szabadság növekedéséhez - ideális esetben az utóbbi legfeljebb hatással lehet az elóbbire. A politikai szabadságtér növekedésére a mobildemokrácia hívei többnyire két releváns példát hoznak fel. Az elsố a Fülöp-szigetek példája, ahol diktátorokat, elnököket emeltek fel vagy küldtek politikai mellékvágányra azáltal, hogy jórészt mobiltelefonok segítségével (lánchívásokkal és SMS-sel) olyan politikai ellenzéki megmozdulásokat szerveztek, amelyek országos méretú demonstrációkká nốtték ki magukat (Paragas 2003, 266-271).

A kötetben szereplô másik történeten túl - amely a mobiltelefon politikai marketingben való hatékony felhasználását példázza (Shing 2003) - megemlíthetố még két magyar példa is: a 2006. szeptember 18-án az MTV székháza ellen intézett támadás, valamint a 2006. október 23-ai ünnepségek során tapasztalt rendốri túlkapások és az azokkal párhuzamosan kitört zavargások. A mobilkommunikációs eszközök éppúgy segítették a politikai megmozdulások szervezését, mint a rendốri beavatkozások irányítását. A késóbbi vizsgálatok során erốteljesen támaszkodtak a telefonos lehallgatásokra, a rögzített mobilhívásokra és az SMS-ekre. Ezek az esetek azonban nem azt támasztják alá, hogy a mobilkommunikációs technikák demokratikusabb környezetet teremtenek: a technika pusztán segítséget nyújt ahhoz, hogy az amúgy meglévő társadalmi, politikai feszültségek könnyebben manifesztálódhassanak. A politikai feszültség egy demokráciában nem valami végérvényesen leküzdendố rossz, hanem természetes velejárója a demokratikus intézményrendszernek. A technika közvetítô eszköz, nem új politikai tényezô.

El kell ismerjük, hogy ezekkel az eszközökkel hatékonyabban szervezhetók meg a tömegdemonstrációk, több ember, rövidebb idó alatt mozgósítható, s ezzel valóban könnyebbé tehetô egyes demokratikus jogok gyakorlása: a szólásszabadság és a gyülekezési jog könnyebben válik érvényesíthetôvé. A mobilkommunikáció legfontosabb politikai vívmánya, hogy segíti bizonyos politikai jogok gyakorlását, ezzel féken tartja a regnáló politikai hatalmat, biztosítja a demokratikus intézményrendszer fenntartásához 
szükséges politikai bizonytalanságot. Korunkat az IKTp több képviselôje is a növekvő bizonytalanság világaként határozta meg. A bizonytalanság, a képlékenység vagy a törékenység (fragility) posztmodernból ránk maradt fogalmait sokan negatív előjellel használják, holott a demokratikus intézményrendszer fenntartása csak a politikai bizonytalanságon, a hatalom számonkérhetôségén, a kormányzat és a képviselók leválthatóságán és visszahívhatóságán keresztül valósítható meg. Ez a fajta bizonytalanság nem a politikai rendszer egészének bizonytalansága, pusztán a politikai hatalom kerül bizonytalanabb pozícióba, ami csak erôsítheti a demokratikus intézményrendszert. Minden jól múködő politikai rendszer lényege a kiszámithatóság, ideális esetben ez szavatolja az állampolgárok és a befektetők számára szükséges biztonságot, nem pedig a képviselók elmozdíthatatlansága vagy a kormányzatnak adott szabad kéz. Minél több pólusú egy politikai rendszer, annál demokratikusabb, még akkor is, ha ez sok esetben lelassítja, túlbürokratizálja a mechanizmusokat. Az állampolgári jogok aktív gyakorlása nélkül (szólás- és gyülekezési szabadság) nincs valódi demokrácia, betegségei elóbb vagy utóbb felszínre kerülnek.

A mobildemokrácia és az IKTp híveinek második példája az e-közigazgatás, amely látható módon szintén támogatja a demokratikus jogok, ti. az állampolgári jogok gyakorlását. Ezzel a kérdéssel a következókben foglalkozom részletesen.

\section{A szolgáltató állam politikai illúziója}

Az alábbiakban arra szeretnék rávilágítani, hogy az e-közigazgatás térnyerése és az erre épüló szolgáltató állam politikai programja a társadalmi valóság demokratizálódásának illúzióját kelti. Az e-közigazgatási programok az internet általánossá válásával, költségeinek csökkenésével és a széles sávú elérések elterjedésével párhuzamosan kezdtek megfogalmazódni az utóbbi egy-két évtizedben. Ahogy ez lenni szokott, némi késéssel nálunk is megjelentek az elsố e-közigazgatási programok. A hazai egykapus e-közigazgatási ügyfél-tájékoztatás vezetô rendszere az APEH rendszerét is bekebelező Ügyfélkapu (www.magyarorszag.hu) lett. Kezdeti gyengeségeiról, kidolgozatlanságáról, , használhatatlanságáról” már többen írtak, s az all-in-one egykapus rendszerek túlméretezettségének problémái is hamar a viták homlokterébe kerültek. Mindezzel együtt mégis üdvözlendô, hogy a kormányzat végre hangsúlyt fektet a mindenki életét megkönnyítố e-ügyintézés fejlesztésére. Olyannyira szívén viseli a kormányzat ezt a törekvést, hogy az Új Magyarország Fejlesztési Terv keretében meghirdetett fejlesztési célok között már konkrétan szerepel az e-közigazgatás. Az Elektronikus Közigazgatás Operatív Program részletesen elemzi a 2013-ig megvalósítandó fejlesztési célokat (NFÜ, 2007). Az operatív program legfóbb célja a közigazgatás teljesítményének javítása és a múködési hatékonyság növelése. E célok megvalósítását a közigazgatási munkafolyamatok megújításán, szolgáltató jellegúvé tételén keresztül kívánja elérni. A program alapjául az Európai Bizottság i2010: európai információs társadalom a növekedésért és a foglalkoztatásért címú dokumentuma szolgál (EKB, 2005). Nem is meglepő, hogy mindkét dokumentum középpontjában kizárólag a gazdasági folyamatok élénkítésének feladata áll. Még az olyan szociálisnak túnố célok is, mint a fogyasztóvédelem, a munkahelyteremtés és a tudásalapú társadalom megteremtése, mind-mind primer gazdasági célokat 
szolgálnak, a politikai és gazdasági célok mögött meg sem jelennek a társadalom számára szintén fontos kulturális és valódi szociális (társadalompolitikai) célok. Egy korábbi tanulmányomban már részletesebben elemeztem, hogy pl. az élethosszig tartó tanulás politikai programja mennyire a „báránybő́rbe bújt farkas” (Faragó 2002). Bayer Judit írása alapján világos, hogy a politikai törekvések az internet megjelenésével szerzett természetes jogok korlátozására, nem pedig a gazdasági és politikai jogok bóvítésére, a szabadságjogok kiteljesítésére irányulnak. Nem az internet múködéséhez szükséges jogszabályi környezet megteremtése ellen érvelek, hanem például a szerzói jogok premodern felfogása iránti görcsös ragaszkodás társadalmi meghaladottságára kívánom felhívni a figyelmet. E téma külön tanulmányt is megérdemelne, így most csak utalni szeretnék rá, hogy az internet által megteremtett hálózati környezet tökéletesen lehetetlenné teszi ezeknek a régról öröklött jogoknak a betartását. A technikai környezet által erốsen formált közgondolkodás (társadalmi tudás) például ma már a legkevésbé sem tekinti lopásnak a digitálisan közzétett video- és hanganyagok letöltését. A szerzôi jog kérdése is egyik jó példája annak, hogy a politikai gondolkodás mennyire nem hajlandó követni az állampolgári gondolkodás és igény változását, a kialakult technokulturális környezetet; téves módon inkább a gondolkodást szeretné a régról megmaradt jogszabályokhoz, jogi normákhoz igazítani, ami szociológiai abszurdum.

A közigazgatás hatékonyságának informatikai eszközökkel történố növelése ugyan fontos feladat, de ez csak a bürokratikus folyamatok felgyorsítását célozza, méghozzá elsôsorban a gazdasági folyamatok felgyorsítása érdekében. A szolgáltató állam programja azt sugallja, mintha az állam jobban oda akarna figyelni állampolgárai véleményére, igényeire, hogy azokat beépítse a döntési folyamatokba. A helyzet azonban éppen ennek ellenkezője: a bürokratikus folyamatok felgyorsítása a kizárólag felülról diktált gazdasági-politikai célok elérése érdekében. Nem véletlen, hogy a politikai elit szívesen támogatja ezeket a törekvéseket, hiszen a szolgáltatóállam-program politikai-pszichológiai hatásai azt az érzetet keltik, mintha az állampolgár demokratikus jogai erôsödnének, holott csak bürokratikus kötelezettségeinek lesz képes hatékonyabban eleget tenni: könynyebben és kevesebb fáradsággal fizeti be az adót vagy az egyes okiratok utáni illetéket, s végre jogot kap arra, hogy megnézhesse hazája jogszabályait, amelyekhez eddig ingyenesen egyszerúen nem juthatott hozzá. Mint a politikai és bürokratikus folyamatok elszenvedóje ugyan rugalmasabban lesz képes intézni ügyeit, de senki sem kérdezi meg továbbra sem, hogy milyen ügyeket is kellene intéznie, és mennyiben kellene a bürokratikus eljárásokat módosítani ahhoz, hogy valóban jobban menjenek az ország dolgai. Az állampolgár csak kötelességei teljesítéséhez és már meglevő jogai érvényesítéséhez kap technikai segítséget, ami ugyan a demokratizálás irányába mutat, de korántsem meríti ki az informatika adta demokratizálási lehetôségeket. Az e-közigazgatás ezért nem jelent valódi előrelépést az e-demokrácia felé.

A politika hamis képet fest az államról, amikor el akarja hitetni az állampolgárokkal, hogy a bürokrácia az a költséges kolonc, amelytôl minden áron meg kell szabadulnia. A „kicsi és olcsó” állam liberális állameszménye mögött a legtöbb esetben a „nagy és drága” pártpolitika igénye áll. A bürokrácia leépítése ugyan költségcsökkentéssel jár, ugyanakkor megnehezíti az állam irányításának folyamatait, kiszolgáltatottá teszi az államkasszát és az államgépezetet. Az amerikai „kisállam”-ideál is politológiai illúzió: csak ott nincs állam, ott nincs politika, ahol az állam nem akar vagy hagyományai miatt 
nem tud jelen lenni. Társadalompolitika nélkül nincs valódi homogén társadalom sem. Pusztán politikai (ideológiai) döntés kérdése, hogy melyik területet töröljük a társadalompolitikai viták repertoárjából, hogy utána a piac hưvösen ölelő karjaiba lökjük. A politika megválaszthatja, hogy mely témákkal foglalkozik, hogy mely téma fontos az ország egésze számára, mely kérdések megoldására hajlandó bürokratikus apparátust létrehozni és múködtetni. Ez a múködtetés igen bonyolult folyamat, kívülról átláthatatlan, össze is fonódik rendesen a primer politikai célok elérésével. Ennek eredménye pedig nem más, mint a hatékonyságától megfosztott bürokrácia, hiszen múködésük valódi célját keresố intézmények csak minimális hatékonysággal képesek múködni. Az így létrehozott eredménytelen és kiszolgáltatott rendszert pedig à politika joggal és következmények nélkül kritizálja a közvélemény előtt, hogy utána ismét politikai eszközként megragadva tovább bomlassza a még múködó mechanizmusokat.

\section{Demokráciaudichotómiák}

A demokráciafogalom részletes elemzésétól terjedelmi okok miatt itt eltekintek, de nem kerülhetem el a demokratikus részeétel formáinak bemutatását, melyet három dichotómián keresztül kísérelek meg igen röviden összefoglalni. Bemutatásuk elengedhetetlennek tûnik a helyzet pontos megértéséhez.

Az elsó dichotómia az individualista vs. kollektív demokrácia. Az elsố megközelítés nagyjából a klasszikus liberális szemlélet társadalomképéból indul ki, ahol a demokratikus intézményrendszer kialakításánál az individuum, az egyéni érdekek, célok és szándékok figyelembevételét tartja elsốdlegesnek. Ez az a ma uralkodó szemlélet, ahol a „kisebbség is számít” jelszava alatt az egyéni érdekek idónként felülkerekedhetnek a kollektív érdekeken. A második fogalom a szocialisztikus elképzelésekhez áll közel, ahol a demokratikus játékszabályok kialakításánál a „,többség a többségért” elv érvényesül, sokszor figyelmen kívül hagyva a kisebbségi jogokat, érdekeket is.

Egy másik dichotómia a direkt vs. reprezentatí demokrácia, amely alapján az ügyek intézését vagy közvetlenül az állampolgárra vagy azok megválasztott képviselőire hagyják. A közvetlen demokrácia legfóbb kritikusai azzal érvelnek, hogy az átlag állampolgár számára követhetetlenek az állam vezetésének feladatai, ezért jobb, ha döntési jogát átruházza választott képviselôjére, aki professzionális módon tudja menedzselni a rá bízott ügyeket - a kritikusok gyakorta hozzáteszik: ez a rendszer rendkívül költséges lenne, hiszen minden kérdésben népszavazást kellene kiírni. A képviseleti demokrácia kritikusai szerint az állampolgár nem képes akaratát érvényesíteni, mert választott képviselóje számos más, fóként pártpolitikai szempont túlzott elốtérbe helyezése mellett gyakorolja a választói képviseletet - e rendszer kritikusai gyakorta hozzáteszik: e rendszer rendkívül korrupt államot teremt, mivel a viszonylag kis létszámú politikai elit döntési pozíciójából fakadóan olyan, a döntését befolyásoló lobbikísértéseknek van kitéve, hogy végül saját anyagi jólétét helyezi elótérbe a választói érdekekkel szemben.

A harmadik dichotómia az elit vs. teljes társadalom részvétele a döntéshozatalban. Az elitek demokráciája Platón államideáljából született modern elképzelés, s alapvetően konzervatív szemléletével azt sugallja, hogy az anyagi és/vagy kulturális elitek képesek csak feleloósségteljes döntést hozni az ország egészének érdekében, míg a kevésbé 
tehetôs vagy kevéssé képzett néptömegek nem képesek kellóképpen átlátni a társadalmi-gazdasági folyamatokat. A teljes (legalábbis a teljes nagykorú) társadalom részvételét hirdetố nézet szerint mindenkinek joga van beleszólni saját sorsának alakulásába, akkor is, ha nem elég tájékozott döntéseinek kimenetelét illetốen.

\section{A képviseleti demokrácia válsága}

„Az e-demokratikus mennyország lehetôsége a semmibe veszett, mivel a Web jelentős része a fokozatosan a kapitalista e-kereskedelem által uralt jövedelmezó piaci területté vált" - írja igen pesszimistán Dányi és Sükösd tanulmányuk bevezetésében (Dányi-Sükösd 2003, 291). Lemondó hozzáállásuk oka az a pesszimizmus, amely - kevés kivételtốl eltekintve - általánossá kezd válni kutatói körökben. Nem a tendenciát szeretném kétségbe vonni, pusztán utalni szeretnék arra, hogy az internet körüli jogszabályi környezet megteremtése még nem jelenti közvetlenül a hálózat teljes kapitalizálódását. Az internet és a vele együtt fejlődố más hálózatok megjelenésének társadalmi hatása óriási, lehetôségei jórészt mindmáig kiaknázatlanok. Ha azok a lehetôségek, amelyek hétköznapivá váltak a társadalmi élet legtöbb területén, nem válnak általánossá, akkor az emberekben könnyen értékfeszüiltség keletkezhet.

Az egyén nem képes magyarázatot találni arra, hogy ha az élet legtöbb területén élhet az e-kommunikáció adta lehetôségekkel, rugalmasan és szabadon véleményt alkothat, miért nem teheti meg ugyanezt mondjuk a politikában is. Miért kellene eltávolítania politikai döntéseit a választópolgárnak magától, amikor az élet minden területén szabadon és közvetlenül dönthet saját sorsáról? Sốt maga a politika várja el tóle, hogy önálló, felelős állampolgár legyen, ne terhelje az államot saját gondjaival, hanem maga oldja meg azokat: ez a felvilágosodás nyomán kialakult embereszmény és politikai ideál vált általánossá az ún. szabad világban. Lemaradásban van a demokratikus intézményrendszer ahhoz az egyre rugalmasabb hálózati környezethez képest, amely a hétköznapjainkban körbevesz bennünket. Az átlag választó egy évtizedben legfeljebb néhány alkalommal dönthet közvetlenül a saját és a közössége sorsát érintô politikai kérdésekról, minden más esetben az általa megválasztott politikai elit dönt a feje fölött. Álláspontom szerint a demokratikus intézményrendszernek igazodnia kell a hálózatok biztosította környezethez, fel kell zárkóznia a társas élet többi területéhez, mert csak a választói döntések közvetlenebbé tételén keresztül kerülhető el, hogy a feszültségek tovább nốjenek, felerôsödjenek a szélsôségek, és a középrétegek teljes politikai apátiába süllyedjenek.

Manuel Castells hálózattársadalom-modellje szerint a nemzetállam elveszti hatalmát, a nemzeti ideológia szétporlad, mindezek helyett a tóke, a technológia, a kommunikáció és a fogyasztás kerül a középpontba - a nemzetállam végeredményben elveszíti az információ kontrolljáért folyó nagy küzdelmet (Castells 1997, 243-259). Castellsnek ugyan igaza van abban, hogy a nemzetállam némiképp kiszolgáltatódik a tókének és a multinacionális cégeknek, ugyanakkor mindenképpen túlzás azt állítani, hogy a nemzetállam ezzel teljesen elvesztené hatalmát és befolyását, mint ahogy a nemzeti ideológia végének víziója is túlzónak túnik. Éppen ellenkezóleg: tipikus kelet-közép-európai jelenség, hogy az antiglobalista mozgalmak sokkal erốteljesebben képesek megszer- 
vezni magukat a jobboldalon, politikai támogatóik, esetleges szavazóbázisuk messze meghaladja a baloldali antiglobalista mozgalmak társadalmi bázisát. Míg az elóbbiek a mérsékelt jobboldalról is lelkes támogatókra lelnek, addig a mérsékelt baloldal éppen a globalizmus elkötelezett híveként definiálja magát. A nemzeti ideológia tehát egyre erốteljesebben talál magára a mindent egynemúsíteni kívánó fogyasztói-globalista típusú liberalizmussal szemben. ${ }^{7}$ Castells egyébként maga is utal az antiglobalizmust jobboldalról támogató csoportokra (defensive communalism), de ezeket csak mint a helyzetet rosszul értékelô, téves ideológiákat, hamis tudatokat mutatja be (Castells 1997, 308). A demokrácia krízisének okát Castells a politikai rendszer elhiteltelenedésében látja: „A médiaaréna csapdájában, az egyszemélyi vezetés foglyaként, a technológia által támogatott manipuláció függésében, törvénytelen pénzügyekkel övezve, a botránypolitizálás szorgalmazójaként és alávetettjeként a többpártrendszer elveszítette varázsát és megbízhatóságát - gyakorlatilag olyan bürokratikus maradvánnyá vált, amely elveszítette a közbizalmat" (Castells 1997, 343). ${ }^{8}$ Ebben a mondatában Castells igen élesen összegzi azt a politikai helyzetet, amely korunk legjelentősebb demokratikus deficitjét jelenti. Máshol is kiválóan mutat rá, hogy a 18. században kialakuló, egykor még progresszív liberális demokrácia hogyan üresedett ki: „Nem arról van szó, hogy ez már csak »formális demokrácia «: vagyis hogy a demokrácia kívül került az olyan lényeges »formákon «, mint a titkos és általános szavazójog vagy a polgári szabadságjogok tisztelete, hanem arról, hogy a demokratikus gyakorlat új intézményi, kulturális és technológiai feltételei elavulttá tették (kiemelés - F. P.) a mostani többpártendszert és a versenyalapú politikai rezsimet a hálózattársadalom politikai reprezentációjának megfelelő mechanizmusok között" (Castells 1997, 349). Pontosan ez az a jelenség, amelyet korábban a politika lemaradásaként jellemeztem. A demokratikus intézményrendszer lépéshátrányba került a társadalmi-technikai változásokhoz képest: ennek felismerése és a politikai változások ösztönzése nélkül aligha kerülhetô el egy komolyabb, a teljes atlanti kultúrát megrengető politikai válság.

\section{Félközvetlen demokrácia}

Castells számára a politikában való aktív állampolgári részvétel 1997-ben még alig jelentett mást, mint a hálózati térben megszervezett vagy közzétett véleménycserét (Castells 1997, 350-351). Ezzel a legtöbb IKTp képviseló szerint is osztott nézettel szemben áll Alvin Toffler álláspontja. „A harmadik hullám” címú 1980-ban megjelent mára klasszikussá vált, magyarra is lefordított - munkájában korunkat Toffler is a nemzetállamok felbomlásának idôszakként jellemzi (Toffler 2001, 334-344). Castells kissé egyoldalú értékelésével szemben Toffler arra is rámutat, hogy a klasszikus nemzetállam fokozatos megszúnése még nem jelenti a nemzetek megszúnését is. Az atlanti államok

\footnotetext{
${ }^{7}$ Másik kérdés, hogy a mai heterogén politikai törekvések mennyiben nevezhetók egyáltalán ideológiáknak, ez a probléma azonban az ideológiák mindegyikét - nem csupán a nemzeti ideológiát - érinti.

${ }^{8}$ A kötetnek létezik magyar fordítása is, tanulmányomban mégis a saját fordításomban hivatkozom a szerzớre, mivel az általam kiragadott idézetek éle elvész a hivatalos magyar fordításban - ez persze nem befolyásolja a magyar fordítás hitelességét, pontosságát.
} 
nyitott, befogadó politikája, a multikulturális lét szükségképpen életre hívja azokat a konzervatív csoportokat, amelyek nem kívánnak osztozni e létforma alapértékein: a multikapitalizmuson és a globális életvitelen, értékrenden. A kifelé forduló állammal szemben elindulnak a befelé forduló nemzeti mechanizmusok: elóbb-utóbb mindenki a saját elveszett értékeit, hagyományait kutatja a kialakult értékválságban, legyen szó a többségi társadalom képviselóiról vagy a kisebbségekról. Nem állítom, hogy ne alakulnának ki új identitások, követhető új értékek a Toffler által is transznacionálisnak nevezett társadalomban, csak arra próbálok rámutatni, hogy ezek nem felelnek meg a társadalom jelentôs csoportjai számára, melyek inkább a gyökereiknél találják meg önmagukat. A harmadik hullám (vagyis az IK'T mindent elöntő áradata) „óriási nyomás gyakorol a nemzetállamra" (Toffler 2001, 344). E nyomás alatt újraértékelődik az állam szerepe és a nemzet fogalma is. Még ma is e folyamat kellós közepében vagyunk, így túl sok biztosat nem állíthatunk e dolog végsố kimeneteléról. Annyit azonban már most is megállapíthatunk, hogy az állam egyre jobban leválik a választói akaratról, a politikai elit pedig egyre inkább próbál önálló életet élni. A nemæet fogalma minden szalonképes politikai törekvés értelmezésében egyre inkább elveszíti etnikai-faji jellegét, fokozatosan kulturális, hagyománykövetố színezetet ölt. Nem csoda hát, hogy a globalizmus kérdésében térségünkben sok, a fenti értelemben vett nacionalista csoport válik antiglobalistává, míg az állam a globalizmus elkötelezett híve marad. ${ }^{9}$

Toffler szerint a harmadik hullám nemcsak társadalmi változásokat indukál, hanem hagyományokat, korábbi társadalmi viszonyokat is életre hív. „A harmadik hullám civilizációjáról [...] kiderül, hogy sok jellemvonása - a decentralizált termelés, a megfelelő méretskála, a megújítható energia, a dezurbanizáció, az otthoni munka és a saját használatra való termelés magas szintje, hogy csak néhányat említsünk - emlékeztet az elsố hullám társadalmainak jellegzetességeire. Olyasmit látunk, ami meglehetôsen emlékeztet bizonyos dialektikus visszatérésre" (Toffler 2001, 364). A globális nyitottság tehát együttjár a koriábbi hagyományok iránti nosztalgiával, valamiféle befelé forduló, a közösséget és privát szférát keresố attitúd megjelenésével. E két tendencia párhuzamosan jelentkezik korunk társadalmaiban, nemcsak az atlanti kultúrában, hanem az egész információs technológia által elárasztott világban is. A nemzetállam felbomlásának tényét sokan kritikátlanul veszik tudomásul, holott ami születóben van, az a legkevésbé sem a nemzetietlen állam.

Castellst megelőzoóen már Toffler is felismerte az IKT-korszak politikájának diszfunkcionális múködését. Toffler azonban nem elégszik meg azzal, hogy a politika döntésképtelenségének okait kutassa, hanem világosan kijelenti: „A harmadik hullám civilizációja nem múködhet a második hullám politikai struktúrájával [...] Ami napjainkban igazán megdöbbentô, az az, hogy kormányaink még egyáltalán múködnek. Egyetlen vállalatigazgató sem kísérelne meg ma egy nagy céget vezetni, ha annak szervezeti felépítését egy olyan 18. századi elôd pennája vázolta volna fel, aki összes menedzseri tapasztalatát egy uradalmi gazdaság intézójeként szerezte. Egyetlen épeszú pilóta sem próbálna meg szuperszonikus repülőgépet vezetni a Blériot vagy Lindberg idejéból

\footnotetext{
9 A multinacionális vállalatok érdekei és a nemzeti, állami érdekek közötti ellentét jelentôségét is érdemes ezen a ponton megemlíteni, ennek részeletes elemzése azonban szétfeszítené tanulmányom kereteit.
} 
való avitt navigációs és vezérló múszerekkel. Márpedig mi nagyjából ezzel próbálkozunk most a politikában" ('Toffler 2001, 425; 447).

A képviseleti demokrácia válságának egyik oka az, hogy a hatalom nem a társadalom egyre nagyobb csoportjainak kezébe jut, hanem a már meglévô politikai elit csoportjai között aprózódik szét olyan mértékben, hogy a felelősségi viszonyok egyre megállapíthatatlanabbak (Toffler 2001, 428). A felgyorsult társadalmi-politikai viszonyok között megjelenő szétaprózódott, relativizált felelősségi körök az állampolgár számára végképp követhetetlenné teszik a politikai aréna eseményeit. Ennek következménye a többségi vélemény széthullása és a demasszifikálódás folyamata, amelynek eredményeként a közéletet tiszavirág életú társadalmi mozgalmak töltik meg. Bourdieu álláspontja aktuálisabb, mint valaha: a közvélemény létének valaha volt illúziója végképp ködbe vész.

A harmadik hullám forradalmi kihívása szemben áll a második hullám elavult intézményeivel, amelyek nem képesek megbirkózni az új kihívásokkal. A politika is érzékeli ezt a helyzetet, ezért szorgalmazza az olyan intézményrendszereknek a harmadik hullámhoz történő igazítását, mint például a közigazgatás. A hatalom bármely társadalmi intézmény átalakítását kikényszerítheti, de saját magával szemben képtelen kényszerítố erốvel hatni. A képviseleti demokrácia válságát a politika nem képes saját erejéból megoldani, a válság azonban nyilvánvaló, a változtatás irányát pedig éppen az IKT kínálja.

„A harmadik hullám kormányzatainak elsô eretnek elve a kisebbségi hatalom (kiemelés - F. P.)" - kezd grandiózus tervének felvázolásához Toffler ('Toffler 2001, 452). A közakarat, a többségi vélemény megszúnésével a tömeg elveszti jelentőségét, helyét az egymás mellett élő, különféle alapokon szerveződő kisebbségi közösségek veszik át, melyek mindegyike saját, időnként egymással szövetségre lépó érdekcsoportokat alkot. ${ }^{10} \mathrm{~A}$ kisebbségek tábora igen sokrétúi; nemcsak a klasszikus nemzeti, vallási, politikai kisebbségekról van szó, hanem a kisebbségi létforma igen széles spektrumáról. A foglalkozásuk, munkakörülményeik, lakóhelyük, egészségi állapotuk alapján egy csoportba kerülő érdekszövetségek éppúgy idetartozik, mint az egyszerú baráti körök vagy az egyes hobbik alapján létrejövő közösségek. A szociológiai adottságok politikailag is egy platformra helyezik az egyes közösségek tagjait, bárhogyan is szerveződjenek ezek a csoportok. A jóléti társadalmakban a szegények is kisebbségbe kerülnek, érdekeik érvényesítése így aligha képzelhetố el valamiféle többségi akaraton keresztül. A helyzet megoldását Toffler az avitt, statikus döntéshozatali mechanizmusok dinamizálásában látja. Az igen széles skálán elérhetố kommunikációs csatornák már most is könnyedén lehetôvé teszik, hogy az egyes érdekcsoportok egymásra találjanak, egyeztethessék érdekeiket, szövetséget alkothassanak.

Toffler - kissé utópisztikus módon - a jelenlegi pártrendszer fenntartása helyett az ún. ideiglenes pártok kialakítása mellett érvel, amelyek így jól leképezhetnék az egyes ad hoc érdekszövetségek politikai akaratát. Koncepciójának nem is ez a része az igazán továbbgondolásra méltó, hanem sokkal inkább az, amely a politikai döntések

${ }^{10}$ Toffler szerint az osztálystruktúra is megszúnik. Klasszikus marxi formája talán valóban, de ezek az. egyes kisebbségi csoportok érdekei időrốl idő́re találkoznak, képlékenységük pedig korántsem akkora, ahogy Toffler gondolta. A kérdés részletes értékelésétól azonban itt ismét el kell tekintenünk. 
részbeni átadására, a félközvetlen demokrácia kialakítására vonatkozik. A koncepció lényege, hogy a pártok visszaadják döntési jogkörük egy részét a választóknak, amelyet azok valamely IKT-hálózat segítségével gyakorolnak. Toffler arról explicite nem nyilatkozik, hogy miért nem kívánja a képviseleti demokrácia teljes átalakítását, de a sorok között olvasva nyugodtan kijelenhetô: Toffler nem az állam jelenlegi múködésének teljes felszámolását kívánja. A koncepció korántsem olyan radikális, mint első hallásra túnik. Sokkal inkább a több kisebbségi csoport által alkotott többség aktív bevonását szorgalmazza a politikai döntéshozatalba. A kötelező oktatási tervekbe épített állampolgári ismeretekkel mélyíthetốk el az állampolgárok politikai ismeretei, akik így hatékonyabban tudnak véleményt alkotni egy-egy szakmai vitáról, amely a végsố öntés meghozatalában komoly támaszt nyújthat. Toffler nem anarchista, nem az államhatalom teljes leépítését szorgalmazza, pusztán a par excellence politikai döntések egy részét szeretné visszaadni a választópolgároknak. ${ }^{11}$ Bár a stratégiai döntések Toffler szerint sem átadhatók, a feszültségek csökkentése érdekében mégis elkerülhetetlen a döntési jogok újraelosztása. Ha figyelembe vesszük, hogy igen rövid időn belül hazánkban is több olyan hálózat áll majd rendelkezésre, amely bárki számára lehetővé teszi a vitákban való részvételt és a közvetlen szavazást, már nem is túnik olyan utópisztikusnak a gondolat. A politika továbbra is a cédulás szavazásban „hisz”, de ez ugyan mely történelmi időszak technológiáját idézi!? Ugyan ki használ ma cédulákat!?

\section{Hálózatdemokrácia}

Castells egyik legújabb tanulmányában több helyen is Toffleréhez hasonló gondolatokat olvashatunk, bár nála még közvetett utalást sem találunk arra, hogy bármit is merített volna az említett szerzố munkáiból. „A politikai intézményeknek létezik egy még mélyebb átalakulási folyamata: egy új államforma jelenik meg, amely felváltja az ipari korszak nemzetállamait [...] Mivel a hálózattársadalom globális, a hálózattársadalom államai nem múködhetnek kizárólag vagy elsốsorban nemzetállami keretek között" (Castells 2006, 15). A nemzetállamot felváltó globális kormányzati formát Castells nem valamiféle globális csúcskormányzatként képzeli el, hanem az egyes kormányok hálózatosodására utal. Kissé eróltetett hálózatmetaforájából nehéz kihámozni, hogy mit is ért pontosan „hálózatosodó kormányzatokon”, ugyanakkor írásaiból világos, hogy a multinacionális tốke és a politika egyre erősödő kapcsolata legalábbis igen erôteljesen van jelen ebben a koncepcióban. Egyszerüen megfogalmazva: a politikai döntéseket egyre inkább a multinacionális érdekek határozzák meg, és egyre kevésbé túnik fontosnak a nemzeti, társadalmi és természeti érdekek figyelembevétele.

Bár Castells a politikai érdekérvényesítés új jelenségei közül továbbra is a hálózati jelenlét által alátámasztott szociabilitást tartja a legjelentősebbnek (a hálózatok mint csoportszervezók a csoportkohézió legfontosabb eszközei), ebben az írásában már megjelenik az eróteljesebb választói részvétel igénye is. „A közszféra reformja irányít min-

11 Többen, részben Toffler is a politikai döntések helyi, önkormányzati szintre küldése mellett érvelnek, ez egy lehetséges alternatíva, de nem válthatja ki teljes egészében a közös ügyekról szóló vitákat, a közös döntéseket. 
den mást a hálózattársadalom hatékony kialakításának folyamatában. Ebbe belatartozik az e-irányítás (e-governance) (az e-kormányzatnál (e-government) tágabb fogalom, amely magában foglalja a választói részvételt és a politikai döntéshozatalt) és az e-egészségügy, az e-oktatás, az e-biztonság és a kommunikációs ipar dinamikus szabályozási rendszerének elegye, amelyeket a társadalmi értékekhez és igényekhez igazítanak. [...] Az ipari korszak racionális bürokratikus állammodellje teljes ellentmondásban áll a hálózattársadalom elvárásaival és folyamataival" (Castells 2006, 17). Világos, hogy Castells kiáll a bürokrácia átalakításának fontossága mellett, és egyre egyértelmúbbek nézetei a közvetlen demokrácia támogatását illetôen is: „a kommunikáció demokráciájának elfogadása a közvetlen demokrácia elfogadását jelenti, valami olyat, amit még soha egyetlen állam sem fogadott el a történelem során” (Castells 2006, 20).

\section{Összefoglalás}

Egyre nyilvánvalóbb tehát, hogy Castells is támogatja-e a közvetlen demokrácia kialakításának valamely törekvését, s ezzel a hálózattársadalom és a harmadik hullám koncepciója azonos platformra kerül. Mindkét koncepció a posztindusztrializmus elvét vallja, vagyis azt a nézetet, hogy korunk társadalmai már nem azonosak az ipari társadalmak közösségével, s ebben az új technológiáknak, az IK'T általánossá válásának komoly szerepe van. Korunk gazdasága és kulturális közege mélyen összekapcsolódik az információs és kommunikációs technológiákkal, s ennek hatására bizonyos hálózati gyakorlatok általánossá váltak. Ezek kulturális beépülése organikus módon ment végbe, amit nem követett tényleges politikai változás. Még mindig egy korábbi kulturális-gazdasági közeg politikai berendezkedése szerint élünk, holott az új technokulturális környezet már más igényeket ébreszt az állampolgárokban. Ami természetes a gazdaságban és a kultúrában, annak természetesnek kell lennie a politikában is - e nélkül értetlenség és társadalmi feszültség keletkezik. A politika nem bújhat sokáig az e-gazdaság és az e-közigazgatás szoknyája mögé, hiszen a bürokratikus végrehajtás technokulturális felzárkózása még nagyobb nyomást fog gyakorolni a hatalom tulajdonosaira. Az egyre növekvő társadalmi feszültség hosszú távon csak a képviseleti demokrácia reformján keresztül enyhíthetô.

\section{Irodalom}

Bayer Judit 2005. A háló szabadsága: Az internet tartalmának szabályozási problémái a véleménynyilvánitás szabadsága tiikrében. Budapest, Új Mandátum Könyvkiadó - Zsigmond Király Fớiskola.

Bell, Daniel 1974. The Coming of Post-Industrial Society. London, Heineman.

Bell, Daniel 1976.The Cultural Contradictions of Capitalism. New York, Basic Books.

Castells, Manuel 1997. The Information Age: Economy, Society and Culture Vol. II. - The Power of Identity. Oxford - Massachusetts, Blackwell Publishers (magyarul: Manuel, Castells: Az identitás hatalma. Budapest, Gondolat - Infonia, 2006).

Castells, Manuel: The Network Society: From Knowledge to Policy. In: Castells, Manuel Cardoso, Gustavo (eds.): 2006. The Network Society: From Knowledge to Policy. Washington, D. C., Johns Hopkins Center for Transatlantic Relations. 
Dányi Endre - Sükösd Miklós 2003. Who's in Control? Viral Politics and Control Crisis in Mobile Election Campaigns. In: Nyíri, Kristóf (ed.): i. m., 285-315.

Európai Közösségek Bizottsága (EKB) 2005. i2010: európai információs társadalom a növekedésért és a foglalkoztatásért. http://eur-lex.europa.eu/LexUriServ/site/hu/com/ 2005/com2005_ 0229hu01.doc: Brüsszel, 1. 6. 2005.

Faragó Péter 2002. A tudástársadalom mítosza. JelKép, 2002/4. 49-67.

Fortunati, Leopoldina 2003. The Mobile Phone and Democracy: An Ambivalent Relationship, in Nyíri, Kristóf (ed.): Mobil Democracy: Essays on the Society, Self and Politics, Vienna, Passagen Verlag, 239-258.

G8 Kyushu-Okinawa Summit (2007): Okinawa Charter on Global Information Society. http://www.mofa.go.jp/policy/economy/summit/2000/documents/charter.html

Kedzie, Christopher 1997. Communication and Democracy: Coincident Revolutions and the Emergent Dictators. http://www.rand.org/pubs/authors/k/kedzie_christopher.html

Mattelart, Armand 2004 [2001]. Az információs társadalom története. Budapest, Gondolat - Infonia.

Nemzeti Fejlesztési Ügynökség (NFÜ) (2007): Elektronikus Közigazgatás Operatív Program. htrp://www.nfu.hu/download/1764/ekop_070703_hu.pdf

Nyíri, Kristóf (ed.) 2003, Mobil Democracy: Essays on the Society, Self and Politics, Vienna, Passagen Verlag.

Paragas, Fernando 2003. Dramatextism: Mobile telephony and People Power in the Philippines, in Nyíri, Kristóf, i. m., 259-283.

Shing, Dong Kim 2003. The Shaping of New Politics in the Era of Mobile and Cyber Communication: The internet, Mobil Phone and Political Participation in Korea, in Nyíri, Kristóf (ed.): i. m., 317-325.

Szalai Erzsébet 2006. Az uijkapitalizmus és ami utána jöhet... Budapest, Uj Mandátum Könyvkiadó.

Toffler, Alvin 2001 [1980], A harmadik hullám. Budapest, Typotex. 